\title{
Late Pleistocene marine terrace deposits in northeastern Brazil: sea-level change and tectonic implications
}

\author{
Alcina Magnólia Franca Barreto ${ }^{a}$, Francisco Hilário Rego Bezerrab,*, \\ Kenitiro Suguio ${ }^{c}$, Sonia Hatsue Tatumi ${ }^{\mathrm{d}}$, Marcio Yee ${ }^{\mathrm{e}}$, Rosemeire P. Paiva ${ }^{\mathrm{e}}$, \\ Casimiro S. Munita ${ }^{\mathrm{e}}$ \\ a Departamento de Geologia, Centro de Tecnologia e Geociências, Universidade Federal de Pernambuco, Campus da UFPE, \\ Cidade Universitária, 50740-530 Recife, PE, Brazil \\ b Departamento de Geologia, CCET, Universidade Federal do Rio Grande do Norte, Campus Universitário, \\ 59072-970 Natal RN, Brazil \\ c Departamento de Geologia Sedimentar e Ambiental, Instituto de Geociências, Universidade de São Paulo, Rua do Lago 562, \\ 05508-900 São Paulo SP, Brazil \\ d Faculdade de Tecnologia de São Paulo, Departamento de Ensino Geral, Praça Coronel Fernandes Prestes 30 , \\ 01124-060 São Paulo SP, Brazil \\ e Instituto de Pesquisas Energéticas e Nucleares, Supervisão de Radioquímica, Rua Travessa R 400, 05508-900 São Paulo SP, Brazil
}

Received 10 January 2001; received in revised form 30 July 2001; accepted 7 September 2001

\begin{abstract}
Coastal areas of passive margins are among the best places to examine the reality of sea-level changes. Elevation of marine terraces is central to interpretation of their approximate age in this kind of tectonic setting. The recognition of Pleistocene shorelines on the South American eastern continental margin is becoming increasingly common, but data are commonly imprecise in both time and space, and the resulting chronology is based mainly on geomorphological attributes. Nine thermoluminescence dates and four optically stimulated luminescence dates of 220-206 ka and 117-110 ka were obtained for two marine terrace deposits along $340 \mathrm{~km}$ of coast in Rio Grande do Norte State, northeastern Brazil. They are correlated with the highstands of marine oxygen-isotope substages $7 \mathrm{c}$ and $5 \mathrm{c}$ sea level, respectively. The older deposit occurs mainly on the $\mathrm{N}-\mathrm{S}$-trending coast and ranges in elevation between 7.5 and $1.3 \mathrm{~m}$. The latter is found along the $\mathrm{E}-\mathrm{W}$-trending coast at altitudes that vary between $1 \mathrm{~m}$ and $20 \mathrm{~m}$. It indicates relative downfaulting of the 220-206-ka marine terrace and uplift of the 117-110-ka marine deposit, which is locally about $12 \mathrm{~m}$ higher than deposits of similar age described $1000 \mathrm{~km}$ to the south. It follows that elevation alone is an unreliable tool for establishing a Quaternary sea-level change chronology also on passive margin coastal areas. (C) 2002 Elsevier Science B.V. All rights reserved.
\end{abstract}

Keywords: marine terrace; Pleistocene; luminescence dating; neotectonics; Brazil

* Corresponding author.

E-mail addresses: alcina@npd.ufpe.br (A.M.F. Barreto), bezerrafh@geologia.ufrn.br (F.H.R. Bezerra), labvidro@fatcesp.br (S.H. Tatumi).

\section{Introduction}

Several studies have pointed out that sea-level changes during the Quaternary have played a sig- 


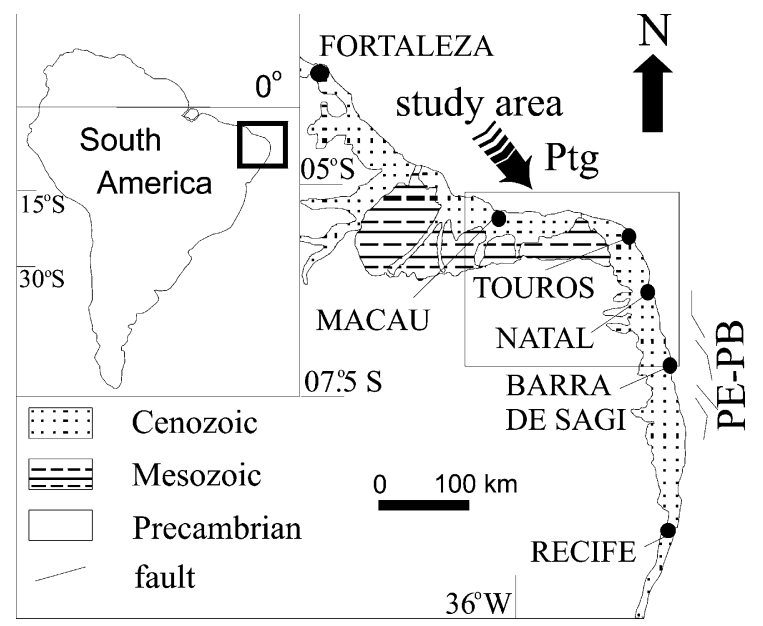

Fig. 1. Simplified geological map of northeastern Brazil and study-area location. Tectonic framework of Pernambuco-Paraíba basin (PE-PB) after Matos (1992).

nificant role in the generation of marine terrace deposits in Brazil (Hartt, 1870; Branner, 1904; Freitas, 1951; Bigarella and Andrade, 1965; Suguio et al., 1985). Much early work on the subject was hampered by uncertainty concerning the eustatic component and poor age constraints. Nevertheless, several marine terrace deposits were mapped and through a combination of geomorphological, stratigraphic, and sometimes paleontological features assigned a relative age. The marine terraces were originally ascribed to the Tertiary, but are today widely considered to be of Quaternary age and have been directly related to glacial and interglacial cycles (Martin et al., 1997).

Pleistocene sea-level changes along the Brazilian coast are not fully understood owing to the scarcity of absolute dates. There is still limited knowledge of Pleistocene terrace age and sea level in Brazil. Pleistocene marine terraces have been described along the Brazilian coast from Rio Grande do Sul State (latitude $\sim 30^{\circ} \mathrm{S}$ ) to Paraíba State (latitude $\sim 7^{\circ} \mathrm{S}$ ) (Fig. 1). Their chronologies rely mainly on relative dating based on geomorphological criteria and in most cases they have not been associated with numerical ages.

The most complete marine records are from the Rio Grande do Sul State (Villwock et al., 1986). Among three barrier-island/lagoon systems re- garded as Pleistocene in age, only system III yielded an age of $35 \mathrm{ka}$ (beyond the limit of the standard radiocarbon method). Its chronology was recognized at several sites along the Brazilian coast. In addition, a few coastal deposits have been dated along the Brazilian coast by thermoluminescence dating (TL) and yielded Pleistocene ages between $130 \mathrm{ka}$ and $59 \mathrm{ka}$ (Ayta, 1996; Barreto et al., 1998, 1999).

Marine terrace deposits prior to $123 \mathrm{ka}$ have not been dated along the Brazilian coast by numerical methods. But eight samples of corals of the genus Siderastrea dated by the Io/U method yielded mean ages about $123.5 \pm 5.7 \mathrm{ka}$ for marine terraces along the Bahia State littoral zone, at about $15^{\circ} \mathrm{S}$ and $39^{\circ} \mathrm{W}$ (Bernat et al., 1983; Martin et al., 1982). Although well exposed in several areas, deposits of this formation in the littoral zone from the south part of Bahia State to at least latitude $34^{\circ} \mathrm{S}$ have not been dated by numerical methods (Martin et al., 1996).

This study provides an extended sea-level highstand chronology back to $220 \mathrm{ka}$. Two marine terraces were identified at seven locations along the Rio Grande do Norte State coast between Barra de Sagi and Macau in northeastern Brazil (Figs. 1 and 2). Both marine terrace deposits have been described previously (Srivastava and Corsino, 1984; Lima-Filho et al., 1995; Lucena, 1997; Testa and Bosence, 1998) but their chronologies have been based largely on stratigraphical and geomorphological attributes. This study indicates that they are 220-206 ka and 117-110 ka and their altitudes above sea level (asl) are different from other marine terraces of the same age described along the Brazilian coast (e.g. Martin et al., 1982; Villwock et al., 1986). The primary goal of this paper is to describe marine terrace deposits in northeastern Brazil, to assess the role of eustatic and tectonic events in their deposition and current altitude, and to correlate them with known Pleistocene highstands in the region. The paper first outlines the coastal and tectonic setting and reviews Pleistocene sea-level changes along the Brazilian coast. It then focuses on chronological, geomorphological, and sedimentary evidence to identify a set of marine terrace deposits. It concludes by interpreting this evidence in terms 


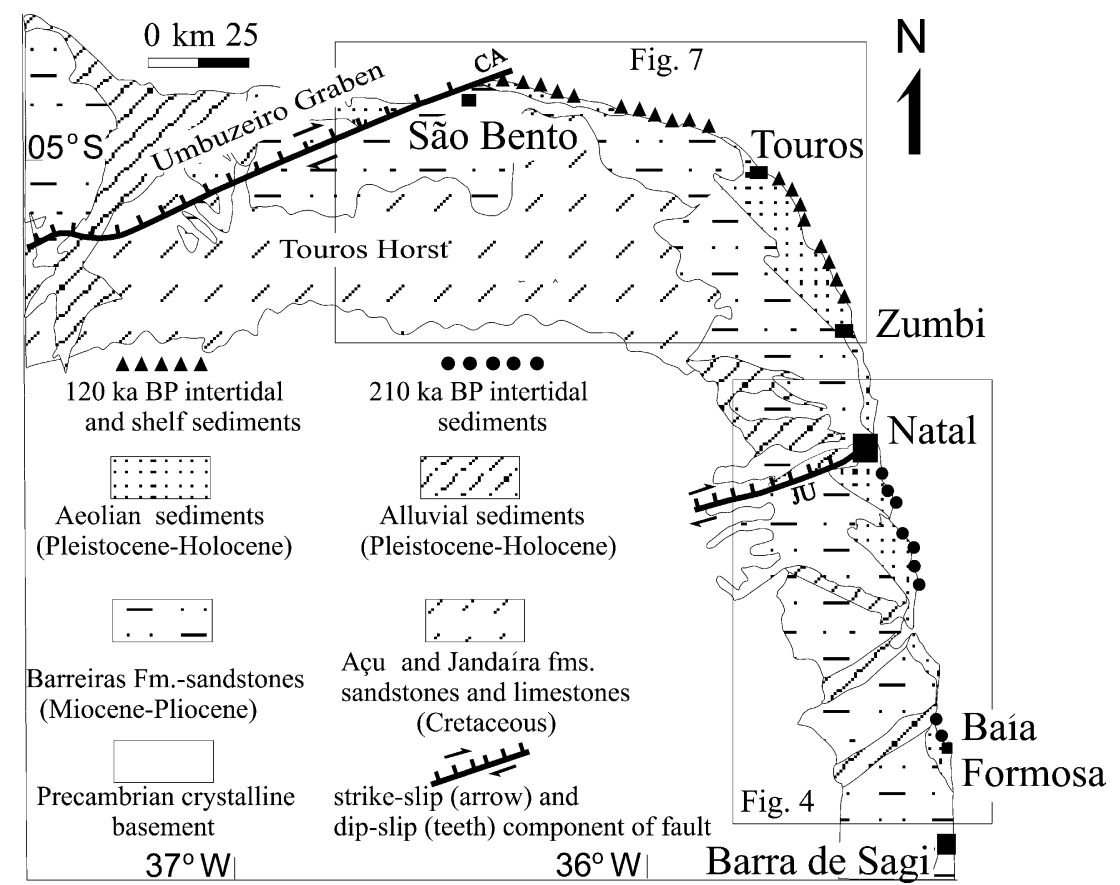

Fig. 2. Geological map showing location of Pleistocene deposits and reactivated faults dated by Bezerra et al. (1998) and Bezerra and Vita-Finzi (2000). CA: Carnaubais, JU: Jundiaí.

of relative sea-level changes in the study area, which are compared with Pleistocene transgressive cycles described along the Brazilian and Caribbean coasts, and by estimating the extent of vertical uplift of the coastal deposits. The results presented here improve the knowledge of Pleistocene sea-level highstands on the South American eastern coast.

\section{Geological and coastal setting}

Along the South American coast, sea-level changes dating from the Quaternary have been proposed to account for the local occurrences of raised marine terraces. Bigarella and Andrade (1965) described shorelines at 50-60 $\mathrm{m}$ and 80$100 \mathrm{~m}$ asl, which they correlated with Pleistocene highstands. Villwock et al. (1986) mapped shorelines at $13 \mathrm{~m}$ above mean sea level in Rio Grande do Sul State (latitude $\sim 30^{\circ} \mathrm{S}$, Fig. 1). They proposed a middle to late Pleistocene age for these deposits on the basis of their height, and corre- lated them with deposits dating from $120 \mathrm{ka} \mathrm{BP}$ at $8 \pm 2 \mathrm{~m}$ asl (penultimate transgression) described by Martin et al. (1982) along the coast of Bahia State (latitude $\sim 15^{\circ} \mathrm{S}$, Fig. 1). The last sea-level highstand along the Brazilian coast, confirmed by numerous radiocarbon dates, was $5 \mathrm{~m}$ high and took place about $5 \mathrm{ka}$ (Suguio et al., 1985).

The study area is situated in a high-energy coastal environment (Martin et al., 1996) where Pleistocene deposits have been exposed by erosion. In addition, the occurrence of emerged, well-preserved and conspicuous marine terrace deposits makes the Rio Grande do Norte State coast an ideal site for a sea-level investigation. The study area embraces part of two Cretaceous sedimentary basins, namely the Potiguar basin and the Pernambuco-Paraíba basin. The most important pre-Quaternary lithostratigraphic units that occur along the coast are Cretaceous fossiliferous marine limestones of Jandaíra Formation and siliciclastic rocks of the Açu Formation, Miocene to Pliocene siliciclastic continental deposits of Barreiras Formation (Suguio and Nogueira, 
1999), capped by Quaternary marine, aeolian, and alluvial deposits. Marine terrace deposits are obscured by aeolian and alluvial deposits in places.

The study area encompasses Cretaceous faultbounded structural blocks, some of which have been active in the Quaternary (e.g., Takeya et al., 1989; Ferreira et al., 1998). The base of the Miocene-Pliocene Barreiras Formation was displaced by as much as $260 \mathrm{~m}$ along the Jundiaí fault on the N-S-trending littoral zone, where sediment-filled fractures dated $4.86-4.57$ cal ka BP were observed (Fig. 2) (Bezerra and Vita-Finzi, 2000). A study carried out by Caldas (1998) and Caldas et al. (1997) across the Carnaubais fault on the E-W-trending littoral zone (Fig. 2) concluded that it offsets a sedimentary succession extending from the Neocomian to the Holocene by $60 \mathrm{~m}$ and controls the local morphology. In addition, Holocene coastal deposits to the east of the Carnaubais fault were uplifted $4-5 \mathrm{~m}$ in excess of the glacio-isostatic predictions. The uplift is matched by downfaulting of coastal deposits to the west of the fault (Bezerra et al., 1998).

\section{Methods of study and luminescence dating}

Altitude measurements of stratigraphic sections were determined by levelling and corrected to two local standard ports: Natal (latitude $05^{\circ} 46^{\prime} 3^{\prime \prime} \mathrm{S}$; longitude $35^{\circ} 12^{\prime} 3^{\prime \prime} \mathrm{W}$ ) and Macau (latitude $05^{\circ} 06^{\prime} 2^{\prime \prime} \mathrm{S}$; longitude $36^{\circ} 36^{\prime} 1^{\prime \prime} \mathrm{W}$ ). Corrections followed procedures proposed by the Admiralty (1996) using tide-table predictions by the Brazilian Navy (2000). Location was determined by reference to the global positioning system (GPS). Marine sediments were sampled away from sunlight.

The chronology of Pleistocene marine deposits along the Brazilian coast has previously been identified on few occasions (e.g. Suguio et al., 1985; Martin et al., 1988) because ages are usually beyond the limit of radiocarbon dating or because of scarcity of carbonate material which has not been recrystallized and which is suitable for dating by other methods such as Io/U. Luminescence dating, however, is not affected by problems relating to organic matter and can be applied to ionic
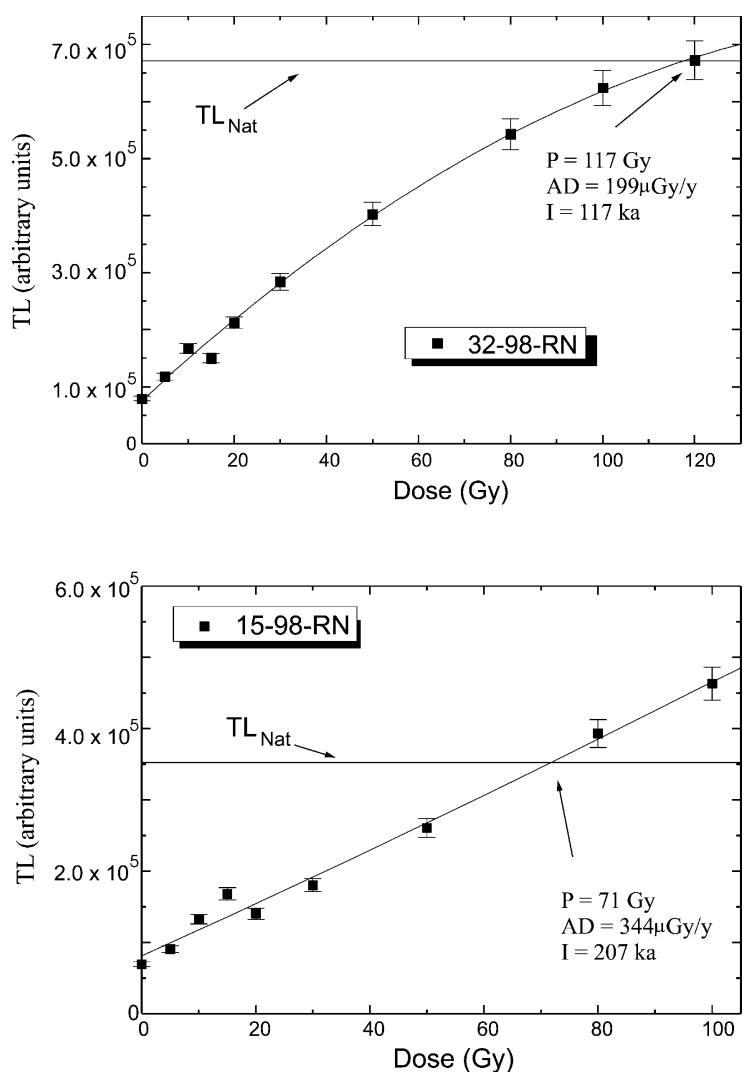

Fig. 3. TL glow curves of two samples discussed in text.

crystals and well beyond the range of radiocarbon dating (Aitken, 1998).

TL and optically stimulated luminescence (OSL) dating of intertidal deposits was carried out at the Laboratory of Glasses and Dating of the Faculdade de Tecnologia de São Paulo (FATEC-SP). Samples were subjected to chemical treatments, followed by sieving to separate grain sizes between 88 and $180 \mu \mathrm{m}$. All $\gamma$-irradiations were performed with a ${ }^{60} \mathrm{Co}$ source of the Instituto de Pesquisas Energéticas e Nucleares - Comissão Nacional de Energia Nuclear (IPENCNEN). Both TL and OSL measurements were performed with a Daybreak Nuclear and Medical Systems Incorporated, Model 1100-Series automated TL/OSL system. We used a dark blue Kopp 7-59 optical filter for TL measurements and the Hoya U-340 filter for OSL measurements. OSL of feldspar and quartz crystals were obtained with IR LED chips $(880 \mathrm{~nm})$ and with a green 
light $(510 \mathrm{~nm})$ from an $860-\mathrm{nm}$ Xe lamp as stimulation sources, respectively.

TL ages were evaluated using total bleach and additional dose methods. OSL ages were obtained using the additional dose method following the multiple aliquot protocol with natural normalization. The annual doses were calculated using ${ }^{235} \mathrm{U}$, ${ }^{238} \mathrm{U},{ }^{232} \mathrm{Th}$ and ${ }^{40} \mathrm{~K}$ concentrations and Bell's equations. The $\mathrm{U}, \mathrm{Th}$, and $\mathrm{K}$ concentrations were measured by neutron activation analysis.

TL glow curves of analyzed samples supplied peaks at 325 and $375^{\circ} \mathrm{C}$. The intensities of the $375^{\circ} \mathrm{C}$ peak were used to evaluate the paleodose and equivalent dose values. They have been linear and supralinear to TL growth as shown in Fig. 3. The majority of OSL growth curves are linear. Table 1 shows radioactivity date concentrations found in the analyzed samples. It was assumed that contribution to cosmic rays was $182 \mu \mathrm{Gy} /$ year for annual dose calculations. Water corrections have not been made due to the low concentrations of dry weight. The paleodoses, equivalent doses and ages of the sediments are shown in Table 2, in addition to one TL age by Yee et al. (2000) also discussed in text.

\section{Pleistocene marine terrace deposits}

Marine sediments yielded ages from $220 \pm 2 \mathrm{ka}$ to $110 \pm 10 \mathrm{ka} \mathrm{BP}$ (Table 2). They form raised marine terraces that overlie Barreiras Formation cliffs in places. The marine sediments are grouped into two informal stratigraphic units, namely the 220-206- and 117-110-ka marine terraces, on the basis of lithologic characteristics, ages, and alti- tude. Five stratigraphic sections exemplify the Pleistocene coastal stratigraphy.

\subsection{0-206-ka marine terrace}

The 220-206-ka marine terrace deposit which is dated by three samples (samples 5-97, 6-97, and 15-98 dated by TL additive dose, TL total bleach and OSL methods, Table 2) crops out along the current shoreline between Natal and Barra de Sagi (Fig. 2), but more conspicuously at the former site, where outcrops are about $1 \mathrm{~km}$ long. Lucena (1997) informally termed these deposits Barra de Tabatinga unit. The deposits range from clayey sandstones to conglomerates. They usually occur in patches along the current shoreline. The top of this deposit is $7.5 \mathrm{~m}$ above mean sea level at Natal. Its base rises from mean beach level to $2.6 \mathrm{~m}$ asl (Fig. 4). Terrace level ranges from about 3 to $5 \mathrm{~m}$ asl.

The 220-206-ka marine terrace was deposited in the intertidal zone. Three main parts, which are marked by beach deposit structures, are clearly observed in outcrops. The lower part of the deposit consist of a wave-cut surface that truncates the Barreiras Formation, forming a clearly defined unconformity, which is marked by a conglomerate layer made up chiefly of highly weathered pebbles of the Barreiras Formation. This basal part shows a lateral continuity of moderately to well-sorted, clast-supported seaward dipping beds. The intermediate part of the marine deposit is characterized by trough cross-bedded and herring-bone cross-bedded sandstone, consisting of coarse to medium-sized well-rounded to subangular quartz grains (Fig. 5). The upper

Table 1

Radioactivity dates and annual dose values found in sediments of Rio Grande do Norte State, Brazil

\begin{tabular}{lllll}
\hline Sample/source & $\begin{array}{l}{ }^{235} \mathrm{U}+{ }^{238} \mathrm{U} \\
(\mathrm{ppm})\end{array}$ & $\begin{array}{l}{ }^{232} \mathrm{Th} \\
(\mathrm{ppm})\end{array}$ & $\begin{array}{l}\mathrm{K}_{2} \mathrm{O} \\
\left(10^{-5} \%\right)\end{array}$ & $\begin{array}{l}\text { Annual dose } \\
(\mu \mathrm{HG} / \mathrm{year})\end{array}$ \\
\hline $5-97(1)$ & $0.25 \pm 0.01$ & $2.25 \pm 0.02$ & $0.226 \pm 0.003$ & $415 \pm 4$ \\
$6-97(1)$ & $0.30 \pm 0.02$ & $0.97 \pm 0.01$ & $2.94 \pm 0.02$ & $332 \pm 6$ \\
$15-98(1)$ & $0.31 \pm 0.01$ & $1.09 \pm 0.01$ & $7.5 \pm 0.1$ & $344 \pm 3$ \\
$32-98(1)$ & $1.20 \pm 0.09$ & $6.76 \pm 0.06$ & $5.81 \pm 0.08$ & $999 \pm 28$ \\
$39-98(1)$ & $1.20 \pm 0.09$ & $6.76 \pm 0.06$ & $5.81 \pm 0.08$ & $999 \pm 28$ \\
$38-98(2)$ & $0.89 \pm 0.06$ & $4.52 \pm 0.04$ & $6.02 \pm 0.07$ & $751 \pm 19$ \\
\hline
\end{tabular}

Sample source: (1) this study, (2) Yee et al. (2000). 


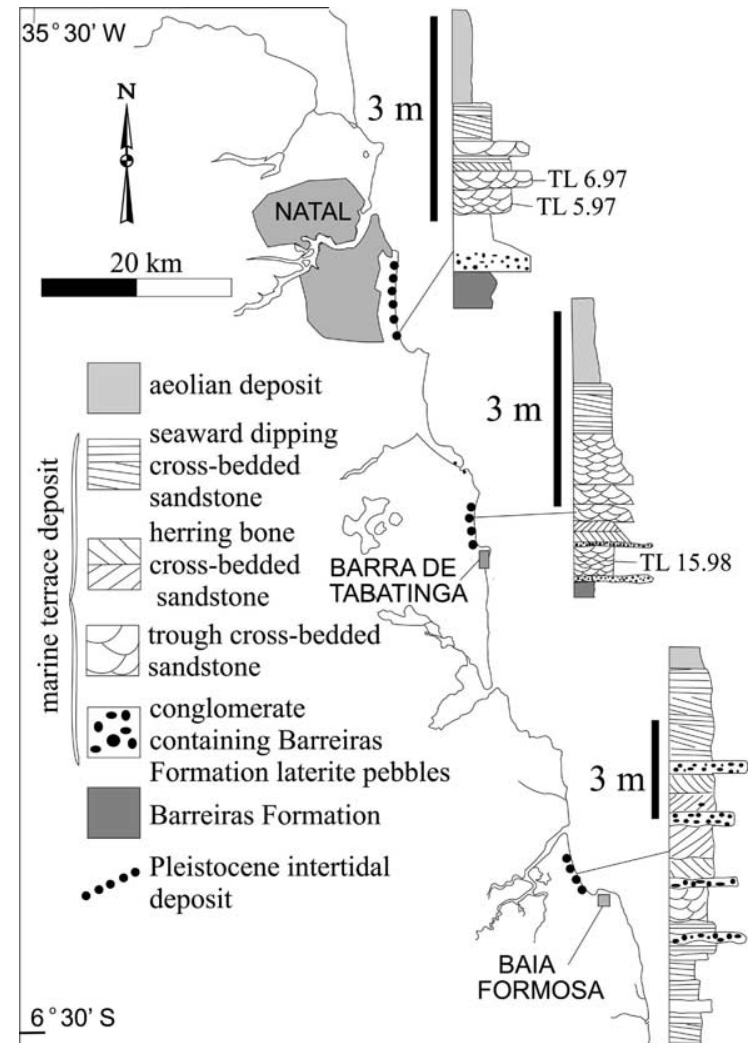

Fig. 4. The 210-ka marine terrace sequence location and representative stratigraphic sections showing sedimentary structures and limits with other main stratigraphic units.

part of this deposit is defined by gently seaward inclined swash cross-bedded, well-sorted quartz sandstone (Fig. 6). Macrofossils were not found but Lucena (1997) identified the foraminifers Glo- bigerina sp. and Quinqueloculina sp. at the base of the unit. These features indicate the intertidal zone. Analyzed samples are from the lower and intermediate parts of these marine terrace deposits (Fig. 4).

The marine terrace deposit about $1 \mathrm{~km}$ to the north of Baía Formosa has not been dated directly but can be correlated with dated deposits at Natal and Barra de Tabatinga on the basis of petrography, sedimentary structures, stratigraphic relations, and geomorphologic features. The base of the marine deposit at Baía Formosa is not depicted in cross-section (Fig. 4), because it overlies the Barreiras Formation at the lower intertidal zone.

Lucena (1997) correlated this terrace with the last transgression that took place along the Brazilian coast in the Holocene at about $5 \mathrm{ka} \mathrm{BP}$ on the basis of deposit height. Nevertheless, six TL dates and three OSL dates for this deposit ranged from $220 \pm 2 \mathrm{ka}$ BP to $206 \pm 5 \mathrm{ka}$ BP (Table 2). In addition, TL and OSL ages that range from $189 \pm 11$ to $186 \pm 10 \mathrm{ka}$ BP obtained by Yee et al. (2000) (Table 2) for aeolian deposits that overlie the 220 206-ka marine terrace deposit are also consistent with new TL and OSL ages presented in this study. The 220-206-ka marine terrace sequence is overlain at many sites by the 189-186-ka aeolian deposit (Fig. 4).

\subsection{The 117-110-ka marine terrace}

The 117-110-ka marine terrace dated by two

Table 2

Paleodoses, equivalent doses and ages found by TL and OSL measurements in sediments from Rio Grande do Norte State, Brazil

\begin{tabular}{lllllll}
\hline Sample/source & $\mathrm{P}$ & $\begin{array}{l}\mathrm{Age}^{1} \\
(\mathrm{ka})\end{array}$ & $\begin{array}{l}Q_{\mathrm{TL}} \\
(\mathrm{Gy})\end{array}$ & $\begin{array}{l}\mathrm{Age}^{2} \\
(\mathrm{ka})\end{array}$ & $\begin{array}{l}Q_{\mathrm{LOE}} \\
(\mathrm{Gy})\end{array}$ & $\begin{array}{l}\mathrm{Age}^{3} \\
(\mathrm{ka})\end{array}$ \\
\hline $5-97(1)$ & $89 \pm 2$ & $215 \pm 7$ & $88.2 \pm 0.1$ & $213 \pm 2$ & $91.3 \pm 0.1$ & $220 \pm 2$ \\
$6-97(1)$ & $70 \pm 9$ & $211 \pm 31$ & $71.5 \pm 0.1$ & $215 \pm 4$ & $68.7 \pm 0.1$ & $207 \pm 4$ \\
$15-98(1)$ & $71 \pm 3$ & $206 \pm 11$ & $71 \pm 1$ & $206 \pm 5$ & $72.2 \pm 0.2$ & $210 \pm 2$ \\
$32-98(1)$ & $117 \pm 7$ & $117 \pm 10$ & $117 \pm 7$ & $117 \pm 10$ & $116.5 \pm 0.5$ & $117 \pm 4$ \\
$39-98(1)$ & $109 \pm 4$ & $110 \pm 10$ & & & & $186 \pm 10$ \\
$38-98(2)$ & $141 \pm 5$ & $188 \pm 11$ & $142 \pm 5$ & $189 \pm 11$ & $140 \pm 4$ & \\
\hline
\end{tabular}

$\mathrm{Age}^{1}=\mathrm{TL}$ age obtained using the additive dose method.

$\mathrm{Age}^{2}=\mathrm{TL}$ age using the total bleach method.

$\mathrm{Age}^{3}=$ OSL age obtained using the additive dose method with multiple aliquot protocol.

Sample source: (1) this study, (2) Yee et al. (2000). 

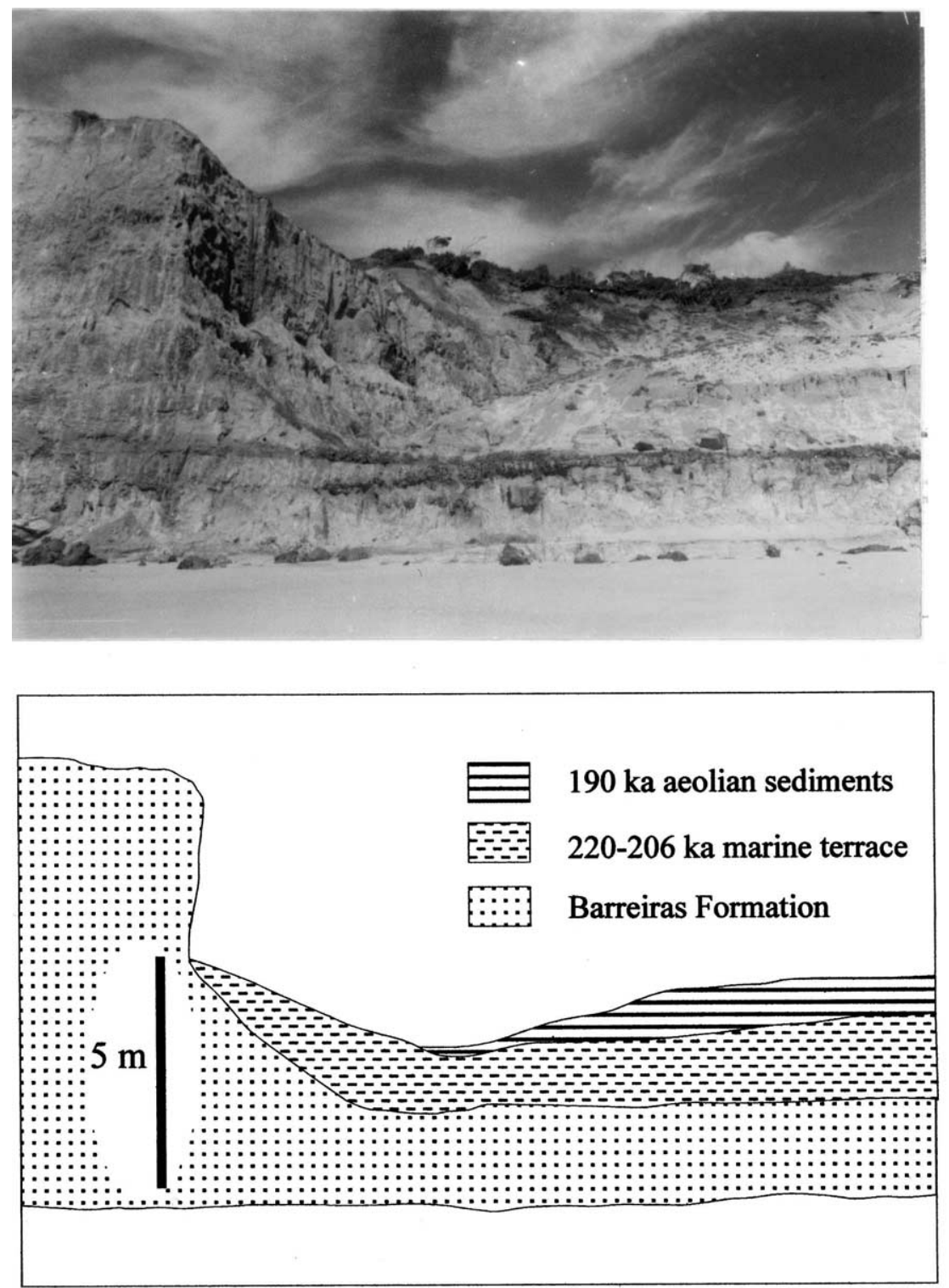

Fig. 5. The 220-206-ka marine terrace incised in a Barreiras Formation cliff at Barra de Tabatinga.

samples (sample 32-98 dated by TL additive dose, TL total bleach and OSL methods; and sample 39-98 dated by the TL additive dose method, Table 2) crops out as cliffs along the current shoreline between São Bento and Zumbi (Figs. 2, 7 and 8). The overlying sediments consist of paleo- and active sand dunes. The 117-110-ka marine terrace deposit is preserved for about $120 \mathrm{~km}$ along mainly the $\mathrm{E}-\mathrm{W}$-trending coast. The most conspicuous outcrops are more than $2 \mathrm{~km}$ long and are situated between São Bento and Touros (Fig. 2). Marine terraces, which are $1-10 \mathrm{~m}$ in altitude between São Bento and Touros, rise to a maximum of $20 \mathrm{~m}$ asl $2 \mathrm{~km}$ to the north of Zumbi.

The São Bento and Touros cross sections typify the 117-110-ka marine terrace stratigraphy. The sedimentary features were described by Srivastava 

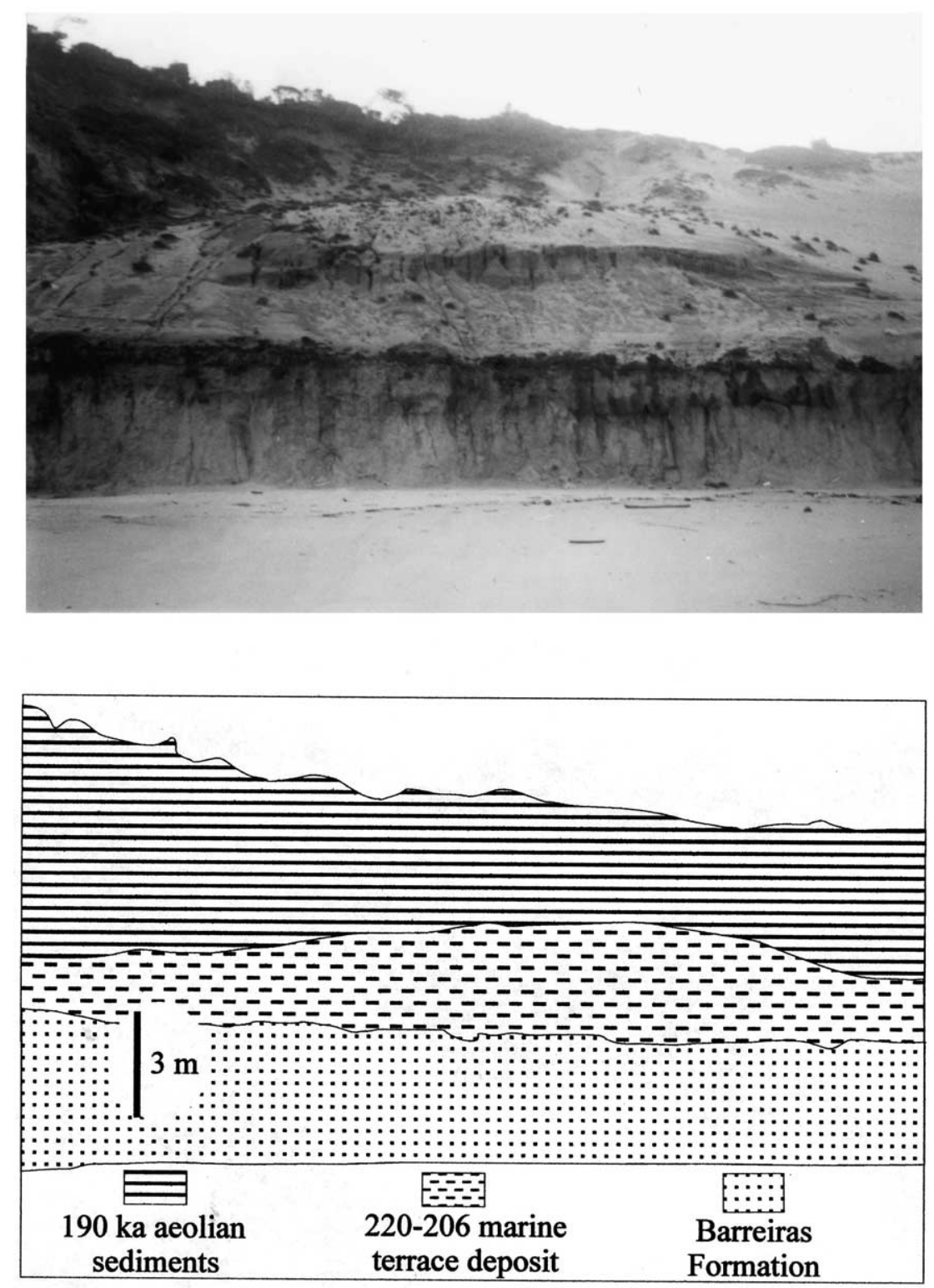

Fig. 6. General view of the 220-206-ka marine terrace deposit overlying the Barreiras Formation and capped by aeolian sediments, outcrop at Barra de Tabatinga.

and Corsino (1984), Lima-Filho et al. (1995) and Testa and Bosence (1998). Deposits are mainly made up of medium- to coarse-grained sandstones. The most common biodetritus is coralline algae, mollusks, and foraminifers (Srivastava and Corsino, 1984). This deposit overlies unconformably the Barreiras Formation (Fig. 9). The basal part of the deposit is composed of coarse to conglomeratic, tabular and trough cross-bedded sandstone. Herring-bone cross-bedded sandstone occurs in places. On the top of the deposit is a swash cross-bedded sandstone, where Ophiomorpha nodosa burrows that form at the beach subenvironment are common. These features, viewed 


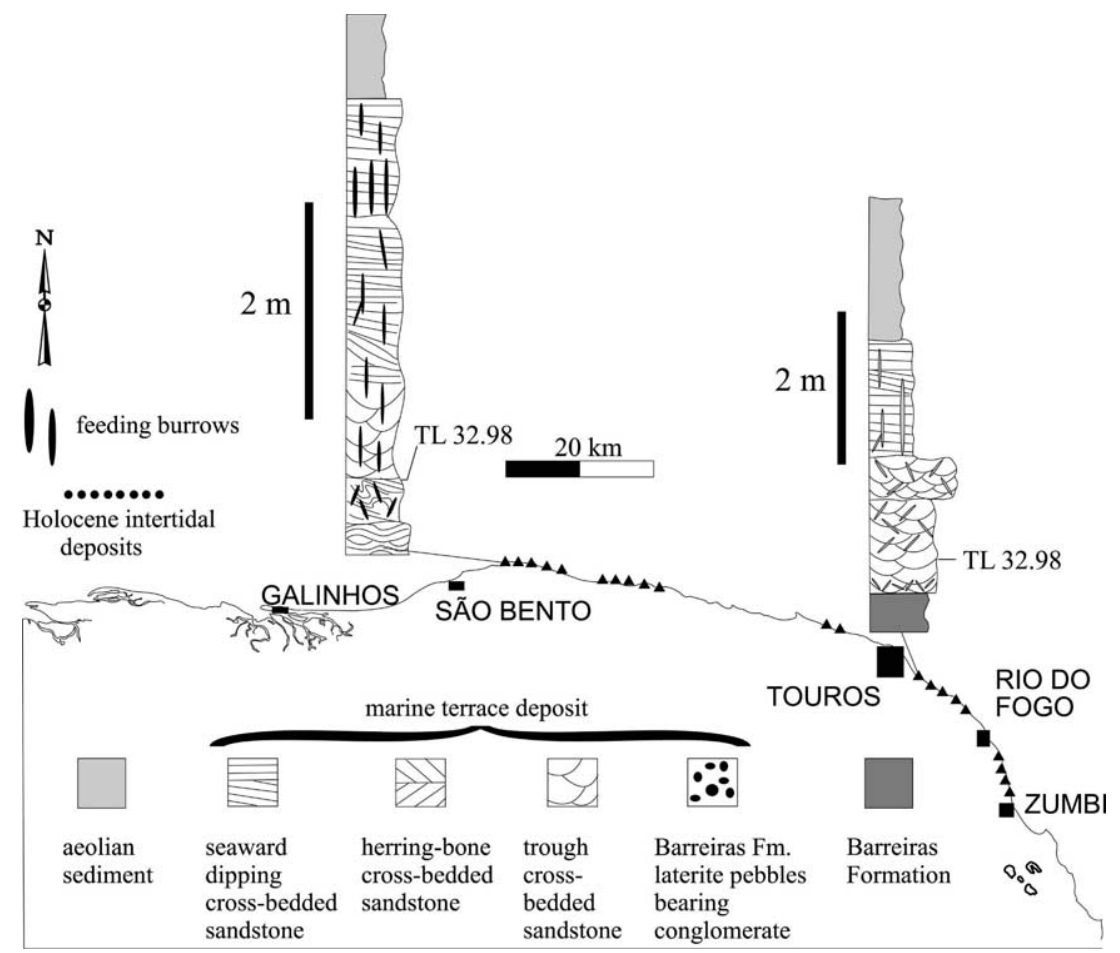

Fig. 7. The 120-ka marine terrace location and representative stratigraphic sections showing sedimentary structures and limits with other main stratigraphic units.

collectively, indicate a high rate of sediment deposition in intertidal to shoreface zone.

A late Pleistocene to Holocene age for these deposits has been suggested on the basis of fossiliferous content and degree of preservation (Campos-e-Silva et al., 1964). ${ }^{14} \mathrm{C}$ ages at $30000 \mathrm{yr} \mathrm{BP}$ indicate that this deposit chronology is beyond the limits of radiocarbon dating (Testa et al., 1997; Testa and Bosence, 1998). X-ray diffraction and scanning electron microscopy indicate that shell contamination and overgrowth of calcite in corals and mollusks from this deposit was too serious or too difficult to remove for reliable radiocarbon dating (Bezerra et al., 2000). They concluded that dates obtained were minimum ages. Two TL ages and one OSL age for a sandstone layer at Touros, and one TL age for a sandstone layer about $15 \mathrm{~km}$ to the west of São Bento, both situated at the base of the deposits (Fig. 7), indicated an age from $117 \pm 10$ to $110 \pm 10 \mathrm{ka} B P$, which corresponds to the last Pleistocene sea-level highstand described along the Brazilian coast.

\section{Discussion}

Resolving the chronology and sedimentary evolution of marine terrace deposits is critical for understanding sea-level changes and coastal tectonics. Despite the fact that marine terrace deposits commonly represent periods of sea levels higher than the current one, the chronology and altitude of marine deposits described in the study area are difficult to correlate with other Pleistocene terraces along the Brazilian coast owing to the small number of available numerical dates.

Until the deficit is rectified one way forward is to correlate Pleistocene marine terraces provisionally with marine oxygen-isotope stages. Fig. 10A shows sea-level highstands and oxygen-isotope stages after Raymo et al. (1990) and Haddad (1994). All three kinds of the 220-206-ka marine terrace dates (TL additive dose, TL total bleach, and OSL) indicate that it formed during oxygenisotope stage 7 sea-level highstand (mainly during substage 7c) (Chappell, 1983; Chappell and 


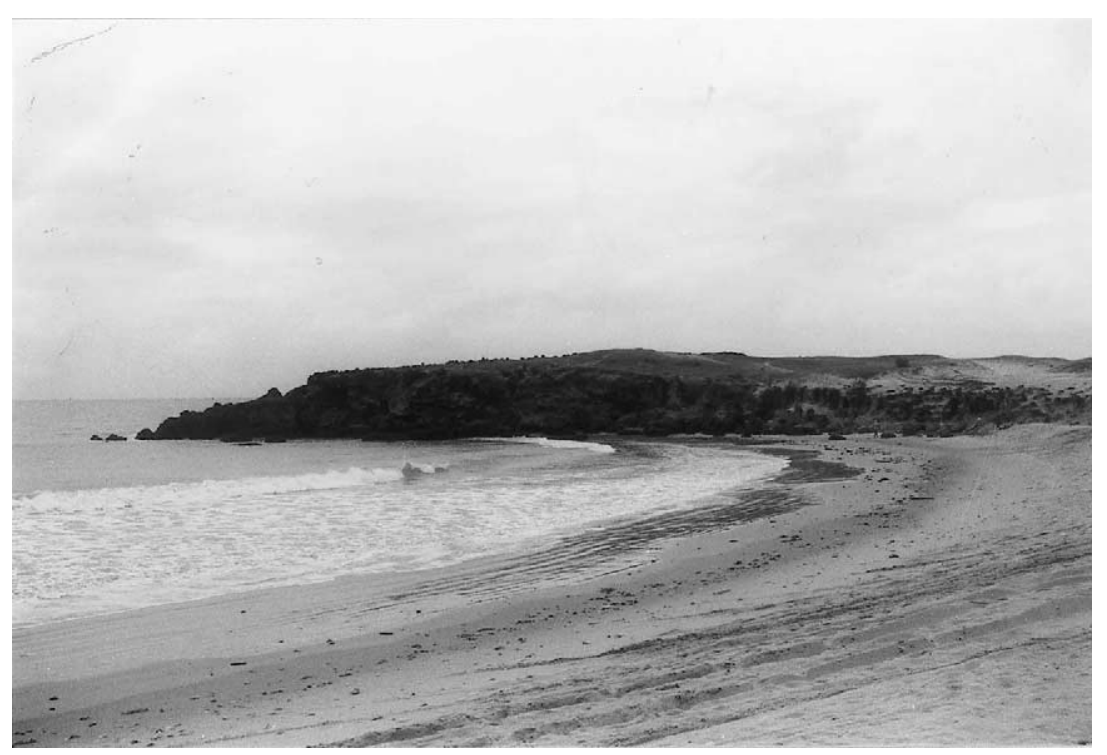

Fig. 8. General view of the 120-ka marine terrace sea cliff at Touros beach.

Shackleton, 1986; Shackleton, 1987; Raymo et al., 1990), which corresponds to the antepenultimate glacial period in the northern hemisphere (Fig. 10A). This interpretation is corroborated by TL and OSL dates on overlying sand dunes (Yee et al., 2000).

The ages from $117 \pm 10$ to $110 \pm 10 \mathrm{ka}$ BP for the youngest marine terrace likewise are consistent with correlation with the sea-level highstand of oxygen-isotope substage 5e (Fig. 10A) (Chappell, 1983; Chappell and Shackleton, 1986; Shackleton, 1987; Raymo et al., 1990) and it corresponds to the last Pleistocene transgressive event or penultimate transgression along the Bra-

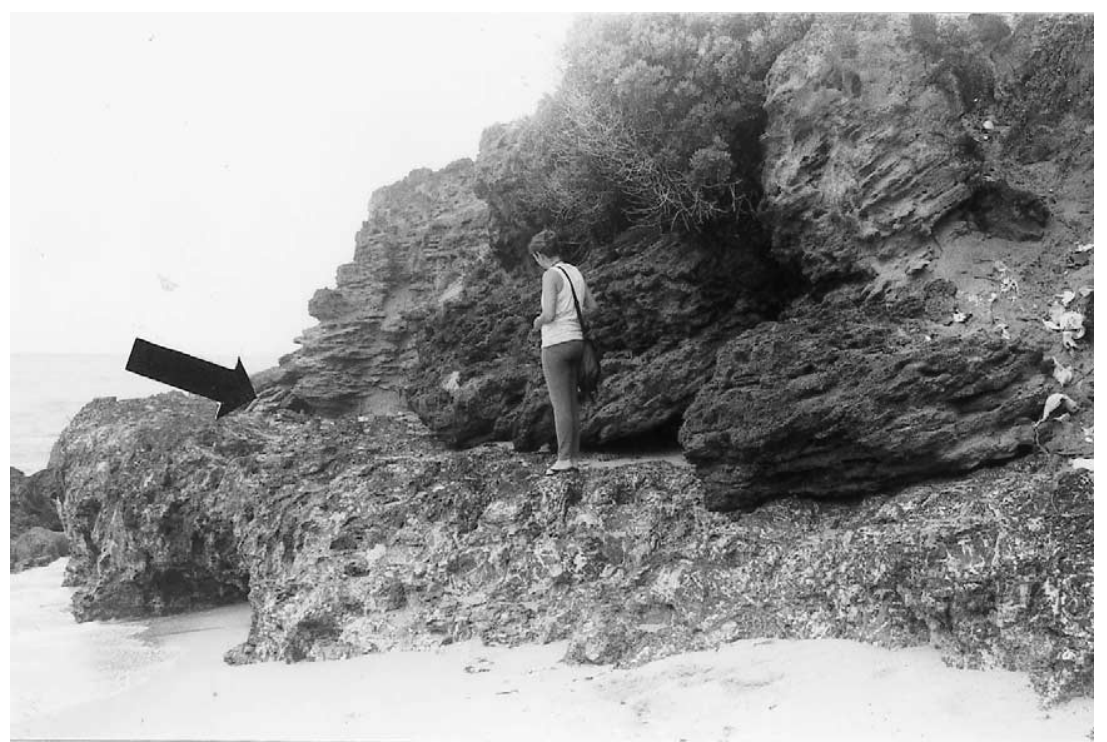

Fig. 9. Miocene-Pliocene Barreiras Formation (BF) overlain by the 120-ka marine terrace sequence $(117-110 \mathrm{ka}) 2 \mathrm{~km}$ east of Touros. The sedimentary unconformity $(\mathrm{U})$ is marked by an arrow. 


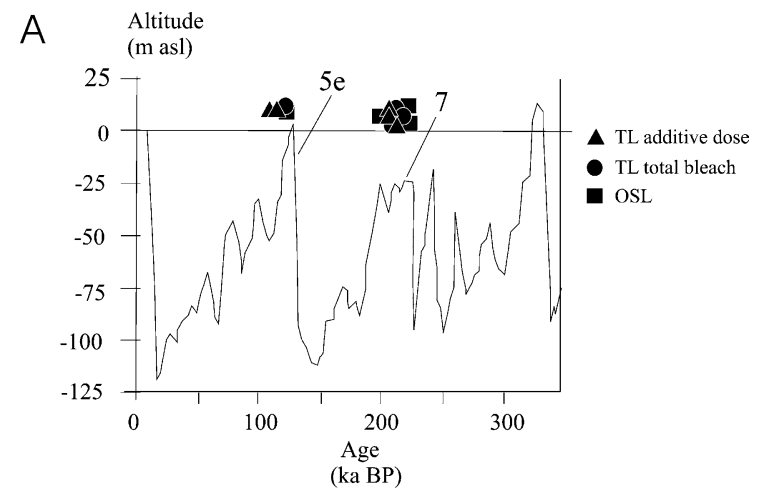

B $\begin{aligned} & \text { Altitude } \\ & (\mathrm{m} \text { asl })\end{aligned}$

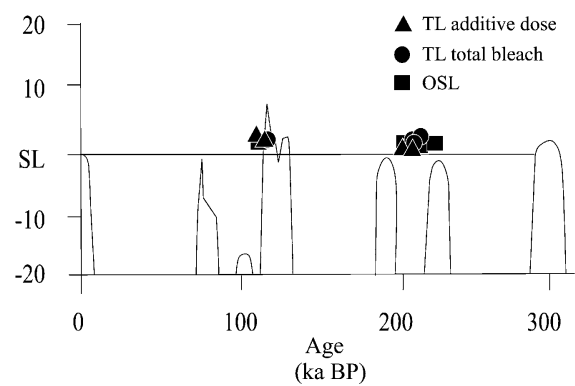

Fig. 10. (A) Correlation of the 210-ka and 120-ka marine terrace sequences from the study area with eustatic sea-level fluctuations over the past $250 \mathrm{ka}$ in Bermudas (modified after Hearty, 1998). (B) Comparisons between marine terrace deposits from the study area and sea-level curve after Haddad's (1994) conversion of Raymo et al.'s (1990) $\delta^{18} \mathrm{O}$ record from ODP core 607 to sea level (in Hearty, 1998).

zilian coast. As the usually accepted maximum elevation for substage 5e sea-level highstand is $6 \mathrm{~m}$ asl (Chappell and Shackleton, 1986; Shackleton, 1987; Raymo et al., 1990), the dates and altitudes (0-20 m asl) of the 117-110-ka marine terrace deposit are consistent with 10-14 m uplift of this deposit since deposition.

Sea-level data from the Bahamas and Bermuda are summarized in Fig. 10B. Pleistocene sea-level fluctuations in the Bermudas and Bahamas include two highstands at about $210 \mathrm{ka} \mathrm{BP}$ and 125 ka BP (Harmon et al., 1983; Lundberg and Ford, 1994; Hearty, 1998; Hearty and Kaufman, 2000). Even though the Bahamas and mainly the Bermuda have had a tectonic evolution very different from that of the Brazilian coast, there is a remarkable coincidence between the sea-level highstand chronologies, mainly that related to the 117-110-ka marine terrace deposit (Fig. 10B).

There is no marine terrace dated by numerical methods described along the Brazilian coast that could be associated with the 220-206-ka marine terrace deposit described here. But the 117-110-ka marine terrace deposit can be correlated with a sea-level highstand in Brazil. The 117-110-ka marine terrace deposit has about the same age as the $123.5 \pm 5.7-\mathrm{ka}$ marine terrace dated by Bernat et al. (1983) $1000 \mathrm{~km}$ to the south of the study area along the coast of Bahia State. But the former is about $20 \mathrm{~m}$ asl, whereas the latter is $8 \pm 2 \mathrm{~m}$ asl. It suggests that the region where the 117-110-ka marine terrace deposit occurs could have been subjected to tectonic uplift by $10-12 \mathrm{~m}$. Some support for this interpretation comes from the suggestion that the 117-110-ka marine terrace deposit situated between Zumbi and São Bento (Fig. 2) represents an uplifted part of coastal deposits (late Cretaceous to Holocene) that occur offshore (Srivastava and Corsino, 1994). In addition, the 220-206-ka marine terrace deposit is $7.5 \mathrm{~m}$ asl, which is much lower than the $20 \mathrm{~m}$ of the top of the 117-110-ka marine terrace deposit. It could be due to downfaulting superimposed by erosion in the coastal area between Natal and Baia Formosa, where the 220-206-ka terrace occurs, or uplift of the area where the 117-110-ka terrace occurs.

\section{Conclusion}

Chronological data indicate that the 220-206$\mathrm{ka}(3-5 \mathrm{~m}$ asl) and 117-110-ka marine terrace (0$20 \mathrm{~m}$ asl) of the Brazilian coast formed during the sea-level highstand of oxygen-isotope stages 7 and 5 , and probably during substages $7 \mathrm{c}$ and $5 \mathrm{e}$, respectively. Marine terraces from Natal to Baía Formosa represent the first along the Brazilian coast to yield ages of 220-206 ka BP. There is a close juxtaposition of the 220-206-ka and 117110 -ka marine terraces along the study area. The 117-110-ka marine terrace deposit has been shown to correlate chronologically with marine terraces that occur at latitude $15^{\circ} \mathrm{S}$ and that are known to have been deposited in the intertidal 
zone during the last Pleistocene marine transgression along the Brazilian coast. It suggests that the littoral zone between São Bento and Zumbi may have been uplifted by at least $10-12 \mathrm{~m}$ since 120 ka BP. These data are consistent with a scenario in which northeastern Brazil has been subjected to differential subsidence or uplift in the late Quaternary. But further investigation is necessary to address this point.

\section{Acknowledgements}

This study was supported by Grant FAPESP Geociências - 97/09974-3. We thank Lars Clemmensen, Finn Surlyk, and Claudio Vita-Finzi for their helpful comments, which greatly improved the manuscript.

\section{References}

Admiralty, 1996. Admiralty tide tables: The Atlantic. Admiralty Hydrographic Department, The Hydrographer of the Navy, Southampton.

Aitken, M.J., 1998. An Introduction to Optical Dating. Oxford University Press, Oxford.

Ayta, W.E.F., 1996. Estudo das propriedades termoluminescentes dos grãos de quartzo dos sedimentos marinhos. São Paulo. MSc Thesis, Instituto de Física, Universidade de São Paulo, São Paulo.

Barreto, A.M.F., Angulo, R.J., Tatumi, S.H., Watanabe, S., Ayta, W.E.F., 1999. Datações por termoluminescência (TL) de sedimentos da planície costeira de Paranaguá, Estado do Paraná. VII Congresso da ABEQUA, Porto Seguro, Bahia, Brazil, viiabequa_zcp038.pdf, Vol. 1. Ed. UFBA, Salvador, pp. 1-4.

Barreto, A.M.F., Lima Filho, M.F., Tatumi, S.H., Manso, V.A.V., Alheiros, M.M., Watanabe, S., Ayta, W.E.F., 1998. Uso da datação por termoluminecência na diferenciação de sedimentos litorâneos pleistocênicos e holocênicos no Estado de Pernambuco. XL Congresso Brasileiro de Geologia, Belo Horizonte - Vol. 1. Anais BH SBG. Núcleo Minas Gerais, p. 263.

Bernat, M., Martin, L., Bittencourt, A.C.S.P., Vilas-Boas, G.S., 1983. Datation Io/U du plus haut niveau marin du dernier interglaciaire sur le côte du Brésil. Utilization du 229 Tl comme traceur. C.R. Acad. Sci. Paris 296, 197-200.

Bezerra, F.H.R., Lima-Filho, F.P., Amaral, R.F., Caldas, L.H.O., Costa-Neto, L.X., 1998. Holocene coastal tectonics in NE Brazil. In: Stewart, I., Vita-Finzi, C. (Eds.), Coastal Tectonics. Geol. Soc. London Spec. Publ. 146, 279-293.

Bezerra, F.H.R., Vita-Finzi, C., 2000. How active is a passive margin? Paleoseismicity in northeastern Brazil. Geology 28, 591-594.

Bezerra, F.H.R., Vita-Finzi, C., Lima-Filho, F.P., 2000. The use of marine shells for radiocarbon dating of coastal deposits. Rev. Bras. Geoci. 30, 211-213.

Bigarella, J.J., Andrade, G.O., 1965. Contributions to the study of the Brazilian Quaternary. Geol. Soc. Am. Spec. Publ. 84, 433-451.

Branner, J.C., 1904. The stone reefs of Brazil, their geological and geographical relations, with a chapter on the coral reefs. Geol. Ser. VII, Museum of Comparative Zoology, Cambridge, MA, $377 \mathrm{pp}$.

Brazilian Navy, 2000. Tide tables for Brazilian ports. www.mar.mil.br/ $\sim$ dhn/tabuas.

Caldas, L.H.O., 1998. Estudo Geológico e Geofísico da Falha de Carnaubais, Bacia Potiguar-RN, e implicações neotectônicas. MSc Thesis, Universidade Federal do Rio Grande do Norte, Natal.

Caldas, L.H.O., Medeiros, W.E., Dantas, E.P., Jardim-de-Sá, E.F., 1997. Caracterização geológica e geofísica de uma estrutura na borda leste do Gráben de Umbuzeiro, Bacia Potiguar/RN, e implicações neotectônicas. Congresso Internacional da Sociedade Brasileira de Geofísica, Rio de Janeiro, Vol. 2, pp. 885-888.

Campos-e-Silva, A., Silva, D.D., Vasconcelos, M.D.T., 1964 Informações sobre a malacofauna dos beach rocks de Touros e São Bento do Norte, Rio Grande do Norte. Arq. Inst. Antropol Univ. Fed. Rio Grande do Norte 1, 79-89.

Chappell, J., 1983. A revised sea-level record for the last 300,000 years from Papua New Guinea. Search 14, 99-101.

Chappell, J., Shackleton, N.J., 1986. Oxygen isotopes and sea level. Nature 324, 137-140.

Ferreira, J.M., Oliveira, R.T., Takeya, M.K., Assumpção, M., 1998. Superposition of local and regional stresses in northeast Brazil: Evidence from focal mechanisms around the Potiguar marginal basin. Geophys. J. Int. 134, 341-355.

Freitas, R.O., 1951. Ensaio sobre a tectônica moderna do Brasil. Bol. Fac. Filos. Ci. Letr. Univ. São Paulo 130 ((Geologia 6)), 1-120.

Haddad, G.A., 1994. Calcium Carbonate Dissolution Patterns at Intermediate Water Depths of the Tropical Oceans during the Quaternary. PhD Thesis, Rice University, Houston, TX.

Harmon, R.S., Mitterrer, R.M., Kriausakal, N., Land, L.S., Schwarcz, H.P., Garrett, P., Larson, G.J., Vacher, H.L., Rowe, M., 1983. U-series and amino-acid racemisation geochronology of Bermuda: implications for eustatic sea-level fluctuations over the past 250,000 years. Palaeogeogr. Palaeoclimatol. Palaeoecol. 44, 41-70.

Hartt, C.F., 1870. Geology and Physical Geography of Brazil. Fields, Boston, MA, 620 pp.

Hearty, P.J., 1998. The geology of Eleuthera Island, Bahamas: a rosetta stone of Quaternary stratigraphy and sea-level history. Quat. Sci. Rev. 17, 333-355.

Hearty, P.J., Kaufman, D.S., 2000. Whole-rock aminostratigraphy and Quaternary sea-level history of the Bahamas. Quat. Res. 54, 163-173. 
Lima-Filho, F.P., Córdoba, V.C., Caldas, L.H.O., Pereira, M.M.V., Fonseca, V.P., Nogueira, A.M.B., Bezerra, F.H.R. 1995. Considerações sobre a geologia costeira de São Bento do Norte/Caiçara, RN: evidências de indicadores do nível relativo do mar. Simpósio de Processos Sedimentares e Meio Ambiente, Recife - Brazil 1, 150-152.

Lucena, R.L.F. 1997. Unidade Barra de Tabatinga - Novas Evidências de um Paleodepósito Quaternário de Praia no litoral Potiguar. XVII Simpósio de Geologia do Nordeste, Fortaleza, CE, Expanded Abstract 168-171.

Lundberg, J., Ford, D.C., 1994. Late Pleistocene sea level change in the Bahamas from mass spectrometric U-series dating of submerged speleothem. Quaternary Science Reviews $13,1-4$.

Martin, L., Bittencourt, A.C.S.P., Vilas-Boas, G.S., 1982. Primeira ocorrência de corais pleistocênicos da costa brasileira. Dataçâo do máximo da Penúltima Transgressão. Ciências da Terra 1, 16-17.

Martin, L., Suguio, K., Dominguez, J.M.L., Flexor, J.M. 1997. Geologia do Quaternário Costeiro do litoral norte do Rio de Janeiro e Espírito Santo. Publication of Fundação de Amparo à Pesquisa de São Paulo e Companhia de Pesquisa de Recursos Minerais 104 pp.

Martin, L., Suguio, K., Flexor, J.M., 1988. Hauts niveaux marins pléistocene du littoral brésilien. Palaeogeogr. Palaeoclimatol. Palaeoecol. 68, 231-238.

Martin, L., Suguio, K., Flexor, J.-M., Dominguez, J.M.L., Bittencourt, A.C.S.P., 1996. Quaternary sea-level history and variation in dynamics along the Central Brazilian Coast: consequences on coastal plain construction. An. Acad. Bras. Ci. 68, 303-354.

Matos, R.M.D., 1992. The northeast Brazilian rift system. Tectonics 11, 766-791.

Raymo, M.E., Ruddiman, W.F., Shackleton, N.J., Oppo, D.W., 1990. Evolution of Atlantic Pacific $\delta^{13} \mathrm{O}$ gradients over the last 2.5 m.y. Earth Planet. Sci. Lett. 97, 353-368.

Shackleton, N.J., 1987. Oxygen isotopes, ice volume and sea level. Quat. Sci. Rev. 6, 183-190.

Srivastava, N.K., Corsino, A.C.R., 1984. Os carbonatos de
Touros (RN): petrografia e estratigrafia. XI Simpósio de Geologia do Nordeste, Natal, Brazil, Expanded Abstracts, pp. $166-175$.

Suguio, K., Martin, L., Bittencourt, A.C.S.P., Dominguez, J.M.L., Flexor, J.M., Azevedo, A.E.G., 1985. Flutuações do nível relativo do mar durante o Quaternário superior ao longo do litoral brasileiro e suas implicações na sedimentação costeira. Rev. Bras. Geoci. 15, 273-286.

Suguio, K., Nogueira, A.C.R., 1999. Revisão crítica dos conhecimentos geológicos sobre a Formação (ou Grupo?) Barreiras do Neógeno e o seu possível significado como testemunho de alguns eventos geológicos mundiais. Geociências 18, 461-479.

Takeya, M.K., Ferreira, J.M., Pearce, R.G., Assumpção, M., Costa, J.M., Sophia, C.M., 1989. The 1986-1989 intraplate earthquake sequence near João Câmara, northeast Brazil Evolution of seismicity. Tectonophysics 167, 117-131.

Testa, V., Bosence, D., 1998. Carbonate-siliclastic sedimentation on a high-energy, ocean-facing, tropical ramp, NE Brazil. In: Wright, V.P., Burchette, T.P. (Eds.), Carbonate Ramps. Geol. Soc. London Spec. Publ. 149, 55-71.

Testa, V., Bosence, D.W., Vianna, M., 1997. Submerged lithologies and their relation with relative sea-level oscillations in Rio Grande do Norte, NE Brazil. VI Congresso da Associação Brasileira de Estudos do Quaternário (ABEQUA), Curitiba, Brazil, Expanded Abstracts, pp. $155-160$.

Villwock, J.A., Tomazelli, J.L., Loss, E.L., Dehnardt, E.A., Horn Filho, N., Bachi, F.A., Dehnhardt, B.A., 1986. Geology of the Rio Grande do Sul coastal province. In: Quaternary of South America and Antarctic Peninsula, Vol. 4. A.A. Balkema, pp. 79-97.

Yee, M., Tatumi, S.H., Suguio, K., Barreto, A.M.F., Momose, E.F., Paiva, R.P., Munita, C.S., 2000. Thermoluminescence (TL) dating of inactive dunes from the Rio Grande do Norte Coast, Brazil. Simpósio Brasileiro sobre praias arenosas: morfodinâmica, ecologia, usos, riscos e gestão. Itajaí, Santa Catarina, Brazil. Universidade do Vale do Itajaí, Expanded Abstracts, pp. 143-144. 